\title{
The Strategy of Islamic Religious Education Teacher in Applying Hidden Curriculum to Increase Student Learning Activeness
}

\author{
Haidir $^{1}$, Muhammad Alfaridzi Matondang ${ }^{2}$, Chairul Azmi Lubis ${ }^{3}$, Aisyah Siregar ${ }^{4}$ \\ Universitas Islam Negeri Sumatera Utara, Indonesia
}

\begin{abstract}
In accordance with the formulation of the problem, this study aims to find out: PAI teachers 'strategies in implementing the hidden curriculum to increase the learning activity of students, Implementation of the hidden curriculum carried out by teachers to increase students' learning activeness, Barriers faced by teachers in implementing hidden curricula and solutions against the obstacles faced by teachers in implementing the hidden curriculum.The research method used is seen from the type of research is qualitative research, and in the data collection process, the authors use the method of observation, interviews and documentation. As for the analysis, the writer uses a qualitative descriptive analysis, which is in the form of written or oral data from the person or actor being observed so that in this case the writer conducts research that describes the actual situation as a whole. The results of the research conducted indicated that, among others: There was a strategy of Islamic Education teachers in implementing the hidden curriculum to increase the learning activity of students. The implementation of the hidden curriculum carried out by the teacher to increase the learning activeness of students is so diverse. There are obstacles faced by teachers in implementing the hidden curriculumas well, the lack of teacher understanding in the use of IT in the learning process, the lack of facilities and infrastructure in the learning process, the presence of students a little late in the learning process. There are various solutions to the obstacles faced by teachers in implementing the hidden curriculum.
\end{abstract}

Keywords

islamic education; teacher strategies, learning activeness of students

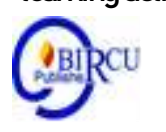

\section{Introduction}

In Law no. 20 of 2003 states that education is a conscious and planned effort to create an atmosphere of learning and the learning process so that students actively develop their potential to have religious spiritual strength, self-control, personality, intelligence, noble character, and skills needed by themselves, the nation's community. and country.

Then Islamic Religious Education is the first step to educate students to produce a quality nation with the principles of Islamic teachings to form a person who is not only intelligent in knowledge but intelligent in spiritual diversity and is balanced with emotional intelligence towards the environment so as to increase faith, understanding, students' appreciation and experience of Islam, so that they become obedient, faithful and obedient Muslim humans to Allah SWT. and have a noble character in personal, social, national and state life.

Talking about education and teachers, it all cannot be separated from the role of the curriculum. In the world of education is very closely related to the curriculum. Various opinions say that the curriculum is the core of education. Education is an interaction between 
educators and students from a teaching process. With education, the curriculum is very helpful for education in achieving goals. To achieve the desired educational goals, the school can develop a planned curriculum. This planned curriculum is usually called a written curriculum or a formal curriculum. In addition, there are other concepts of the curriculum, namely the hidden curriculum.

In carrying out the curriculum, a teacher really understands how to learn in the classroom to be active so that education looks quality. It should be noted that learning is a characteristic of humans so that humans can be distinguished from animals. Learning is done by humans throughout their life, anytime and anywhere, whether in school, class, on the streets, and in a time that is not determined before. Even so, human learning is always carried out by a certain intention and purpose. (Oemar Hamalik, 2004: 154)

To create active learning, the teacher must prepare strategies in carrying out the learning process in the classroom so as to lead to student activity in learning. We see that when learning it will generate a strong response, such as students like to ask questions, answer questions from teachers and friends, assignments on time, discipline and others. Conversely, students who do not learn will show a decreased response, for example lazy to take notes, not doing assignments and talking with friends while studying.

Therefore, teachers need strategies in creating learning activeness of students by implementing a hidden curriculum because strategy is a method used by teachers to deliver subject matter that can provide learning experiences for students. The role of teaching strategies is very important when teachers teach students who are different in terms of abilities, achievements, inclinations and interests. Here, the teacher not only has to master various teaching principles, but what is more important is to integrate and compile the rules to form the most memorable teaching strategy in his teaching.

\section{Review of Literatures}

\subsection{Strategy Teacher}

The word strategy comes from Latin, namely "strategia" which means the art of using plans to achieve goals. In general, a strategy is a tool, plan, or method used to complete a task. In the Big Indonesian Dictionary, strategy is careful planning of activities to achieve specific goals (desired).

According to Dick and Carey, there are 5 components of learning strategies, namely preliminary learning activities, information delivery, student participation, tests and learning activities. First, preliminary learning activities. Second, delivery of information. Third, the participation of students. Fourth, test. There are two types of tests or assessments commonly carried out by most educators, namely pretest and posttest. Fifth, follow-up activities. Followup activities, in principle, have to do with the results of the tests that have been carried out, because the essence of continued activities is to optimize student learning outcomes.

With regard to learning strategies, the teacher has a strategic role in designing a strategy, technique, or approach that is deemed appropriate for achieving learning objectives (Sulasmi, 2020a). As a designer in learning, the teacher is very instrumental in determining the success or failure of the achievement of learning objectives. So that learning objectives can be achieved, teachers are required to have skills and can organize materials in such a way that the learning materials become interesting and challenging. But now there is a tendency that teachers often use learning techniques that do not foster the potential of students' thinking, attitudes, and skills (Akrim, 2020). 


\subsection{Islamic Religious Education Teacher}

Education is one way to produce quality Human Resources (HR) with experience changes in knowledge, skills and attitudes. These changes can be a capital to improve selfcompetence in facing the era of globalization that always undergo the change (Sitorus et al, 2019). Education that is carried out from time to time is always changing in accordance with the times. Therefore, teachers as learning managers are required to be more creative and innovative in order to make learning outcomes more optimal (Sipatung et al, 2020).

In the Law of the Republic of Indonesia number 14 of 2005 concerning teachers and lecturers regarding qualifications, competencies, certification of teachers and lecturers. Has explained the competencies that must be possessed to become a professional teacher, including pedagogical competence, personality competence, social competence, and professional competence obtained through professional education (RI Law Number 14 of 2005, 2011, 23).

Finally, from the above opinion it can be concluded that Islamic Religious Education is an effort to prepare and educate students to form potential and talents in students in accordance with Islamic teachings that come from the Koran and Sunnah so that they can get a more perfect life and a happy life. Islamic religious education teachers are professional educators with the main task of educating, teaching, guiding, directing, training, modeling, assessing and evaluating students through providing knowledge and experience in accordance with Islamic teachings.

\subsection{Hidden Curriculum}

Hidden Curriculumconsists of two words, namely hidden and curriculum. Etymologically, hidden which comes from English, namely hide which means hidden or hidden and hidden (hiding). (John M. Echols and Hassan Shadily, 2005: 297)

According to Murray Print also states that the hidden curriculum is events or activities that occur and are not planned for their existence, but teachers can use them to achieve learning outcomes. Meanwhile, according to Glattrohn, as quoted in the book Paradigm of Islamic Education by Dede Rosyada, the hidden curriculum is defined as a curriculum that is not studied, but as an aspect of school outside the studied curriculum that can influence students' values, perceptions and attitudes. The point is that the hidden curriculum, according to Dede Rosyada, is the school habit of applying discipline to its students, such as the accuracy of the teacher in starting lessons, the ability of teachers to master the class, and habits that can change the way students think and behave. (Murray Print, 2008: 30)

\subsection{Learning Activity}

The activeness of children in learning is an important and fundamental issue that must be understood, realized and developed by every teacher in every learning process, and also means that it must be applied by students in every form of learning activity. Active learning is characterized by optimal involvement, both intellectually, emotionally and physically if needed. The natural activity of the child will be able to develop in a positive direction if the environment provides a good space for the growth of that activity. (Aunurrahman, 2012: 119)

So, we can conclude that the notion of active learning is a physical or mental activity that involves students' intellectual-emotional learning activities. It can also be said that active learning is characterized by optimal involvement, both intellectually, emotionally and physically if needed. 


\subsection{Learners}

Learners are one of the human components that occupy a central position in the teaching and learning process. In Arabic, there are at least four terms that indicate the meaning of students, namely, pupil, al-tilmidz, muta'allim and al-thalib. Murid comes from the word 'arada, yuridu, iradatan, disciplinan which means one who wants (the willer). This understanding shows that a student is a person who wants to gain knowledge, skills, experience, and good personality for his life provisions so that he is happy in the world and the hereafter by means of serious learning.

So, we can conclude that the understanding of learners is someone who is looking for knowledge, experience, and skills and the formation of their personality to make changes in their life, namely changes related to aspects of knowledge (cognitive), attitude (affective') and skills (psychomotor).

\section{Research Methods}

Data analysis in qualitative research is carried out during data collection and after completing data collection within a certain period. The data analysis technique in this study will use the data analysis technique of the Milles and Huberman model, in which they reveal that the activities in qualitative data analysis are carried out interactively and continue continuously to completion. Activities in data analysis, namely data reduction, data presentation, and conclusions or verification.

\section{Result and Discussion}

\subsection{General Findings}

SDN.136539 was first established in 1981, SDN. 136539 is located in the city of Tanjungbalai which is located at Jl. Anwar Idris, Ex. Bunga Tanjung, Kec. Datuk Bandar Timur. As for the school's vision, namely: creating students who are intelligent, skilled, creative, piety and have noble character and achievements who are environmentally friendly and can preserve the surrounding environment. For the school's mission, namely: carrying out learning activities with applicable provisions, implementing learning programs that have religious teachings, fostering self-confidence for students, motivating / encouraging students to be skilled in writing, reading and arithmetic, fostering a sense of care towards the surrounding environment, fostering high discipline in improving environmental quality and creating a clean and healthy environment. Based on the results of interviews with SDN teachers. 136539 that students in this school are very active in the teaching and learning process with the implementation of a hidden curriculum in the learning process. The students are said to be students who excel, pious and sholeha. Students are also very ethical in speaking and are friendly to teachers and their peers.

In supporting the success of the educational process, it requires teaching staff who have basic teaching competencies, as is the case with SDN. 136539 really need teaching staff in order to complete effective teaching and learning activities. There are 20 teaching staff with the potential to transfer knowledge to students. The school is looking for teachers who are still young because they are expected to change the paradigm of older senior teachers in order to create an effective learning climate with the various creativities of the teachers. Creating a pleasant atmosphere in the classroom can encourage students to be more active in the teaching and learning process. 


\subsection{Special Findings}

There are many methods that can be used in the learning process. Basically, the purpose of using learning methods is to obtain success or success in achieving learning objectives. In delivering the subject matter, the teacher should choose a method that is in accordance with the material to be delivered in accordance with the circumstances of the students. In delivering PAI subject matter in implementing a hidden curriculum to increase the learning activeness of students, teachers of Islamic Education at SDN. 136539 using different methods, according to the subject matter to be delivered. Based on the results of an interview with a politician at SDN. 136539 who carry out the mandate as a teacher of Islamic Religious Education. I interviewed the teacher I was researching who served as an Islamic Religious Education teacher at SDN. 136539 regarding the understanding of Mother Marhaeni Sitorus, S. Pd. These are about hidden curricula, hidden curriculum forms and PAI teacher strategies in implementing hidden curricula to increase student learning activity: "As we know Islamic religious education is an effort to nurture and nurture students so that they can always understand Islamic teachings with enthusiasm, iklas, tawaddu 'and of course sourced from the Qur'an and Hadith and can implement Islamic teachings in everyday life. And the duty of the mother as a teacher of Islamic education, is an effort to educate, teach, guide, direct, train, model, assess and evaluate students through providing knowledge and experience in accordance with Islamic teachings.

Mother's understanding of the hidden curriculum is a curriculum that is not a part that must be studied but is able to increase the learning activity of students or what is seen, heard, felt is included in the hidden curriculum".

"The hidden curriculum forms that mothers do to increase the learning activeness of students who remember, such as when studying, mothers position the students' sitting positions according to their level of knowledge and characteristics, mothers always provide motivation to students who ask and answer. in the form of cues or values, mothers invite students to applaud one of the students who are active in learning, in the learning process, mothers always test the memorization of the al-qur'an in the form of short surahs and many more.

The strategy is the method chosen to deliver subject matter in a teaching environment that can provide learning experiences to students. And teaching methods and techniques are part of the teaching strategy. And the strategies commonly used to increase the learning activeness of students are active learning strategies, contextual learning strategies, theme quizzes and demonstrations.

Based on observations made by researchers at SDN. 36539, it is true that SDN. 36539 implements a hidden curriculum in the learning process with the strategies and methods used by each teacher. And PAI teachers have understood what is meant by hidden curriculum, carried out various forms of hidden curriculum and used active learning strategies, contextual learning strategies, team quizzes, and demonstrations to improve student learning outcomes in SDN. 136539. To prove the implementation of the hidden curriculum that was carried out at SDN. 36539 Tanjungbalai, in particular, it focused on research conducted by researchers in the subject area of Islamic Religious Education which was studied in class VI B, totaling 29 students. Which is where the PAI teacher carries out a hidden curriculum to increase the learning activeness of students, namely: In the learning process, each student is required to say greetings and basmallah when asking questions and responses so as not to stutter in asking questions and giving responses. Then at SDN. 136539, for class VI, it is mandatory to know about prayer intentions, prayer movements and the number of cycles of prayer and call to prayer. So, in the learning process before starting lessons, the teacher instructs some students to practice prayers, with that students are very happy to come forward because they want to be praised as smart, pious and pious students. 
In the learning process, students were instructed to make an accusation position such as the letter (U) during the lesson on the story of the Prophet's Tauladan because one of the students was ordered to read the story of the Prophet's Examples and the student sat in the position of the letter $(\mathrm{U})$ and listened carefully. The teacher checks the hair, nails, clothes and all the appearance of students in order to get used to living clean and tidy because in Islam, cleanliness is part of faith and so that in learning, students can be active in learning and enthusiastic in learning. During the learning process, the teacher positions the students' seats according to their level of knowledge and characteristics.

The teacher always provides motivation to students who ask and answer in the form of additional cues and values. In the learning process, if students seem noisy, bored and bored. The teacher invites students to sing in Islamic nuances such as the song "Sepohon Kayu" or the teacher arouses students' enthusiasm by inviting chants. Like, the teacher says Islam, the student answers that Muslims are Beautiful. When the learning process took place, one of the students was instructed to advance to explain what was understood about the material being studied, for example the material "The Beautiful Names of Allah SWT". After one of the students is able to explain, the student has the right to choose one of the other friends to come forward to explain the same material and the student who has previously explained has the right to sit. In that process, the teacher motivates students to move forward and rewards in the form of value. To increase learning activity, sometimes the teacher goes around to monitor students who are less disciplined, such as sleeping on a bench, telling unnecessary stories, hitting friends and so on. So, the teacher gives a light punishment, such as testing the memorization of the surah or asking for previous material.

In the learning process, when reading the material "The Beautiful Names of Allah SWT", which consists of 4 parts of the material, namely: as-samad, al-muqtadis, al-muqaddim and albaqi '. At that time, to increase learning activity, after the teacher explained the material, the teacher ordered 4 students to explain each one of the parts of the material. If, are brave and succeed in explaining the material, then the student will be given additional marks. At the beginning of learning, the teacher has repeated it in a unique way. For example, the teacher gave 4 gifts, in the form of a notebook and in the book a question that discussed the previous material was inserted. For example, in the first book, state the names of the last days. If you are successful in answering, you will get the book. With that, students are excited to learn and continue to repeat lessons at home. Sometimes, in asking or responding, the teacher only appoints disciplined students. For example, not telling stories with friends while studying and neatly dressed.

At the beginning of the lesson, the teacher instructs students to pay attention to their surroundings if there is trash to throw into the trash. And sometimes the teacher explains to students to create a clean and healthy environment so that learning feels calm and active in the learning process. Based on the results of research at SDN. 36539. PAI teachers have implemented a hidden curriculum to increase the learning activeness of students with various strategies and methods adapted to the conditions of students and the class. To foster active learning of students at SDN. 136539 Tanjungbalai, there are several factors that support it, so that there is a strong impetus so that students can be active through teacher strategies in learning.

In increasing learning activeness at SDN. 136539 Tanjungbalai, there are several supporting and inhibiting factors, namely: (a) Supporting factors. With this study, the researcher interviewed directly with an Islamic Religious Education teacher named Marhaeni Sitorus, S. Pd. served in SDN. 136539, namely: "The strategy is the method chosen to deliver subject matter in a teaching environment that can provide learning experiences to students. And teaching methods and techniques are part of the teaching strategies and strategies commonly 
used to increase the learning activeness of students, namely active learning strategies, contextual learning strategies, theme quizzes and demonstrations.

In this case, to strengthen the results of the observations made by the researcher, the researcher conducted an interview with one of the students during a break in class, these students were Muhammad Alif Arfandi, Putri Amelia and Afnan Aritonang, namely: The opinion of Ananda Muhammad Alif Arfandi is: "For me, learning Islamic religious education is very important because learning Islam can fulfill human curiosity about the values of good and bad, can be a guide or give direction to humans who want to do good, can encourage the human spirit. to do good and direct human morals to a better, polite and moral direction.

After carrying out a direct review of the field to be precise at SDN. 136539 Tanjungbalai from field notes, interviews and documentation studies, the researchers found several findings which are described as follows:

a. The Strategy carried out by Islamic Education Teachers in Implementing a Hidden Curriculum to Increase the Learning Activeness of Students at SDN 136539 Tanjungbalai

The learning methods used by teachers at SDN. 36539 Tanjungbalai are quite varied, and run quite well due to factors that make it easier for teachers to apply these methods. In the teaching process, the teacher does not only explain and convey a number of subject matter to students, but the teacher also provides encouragement and encouragement so that the learning process occurs in students. With the existence of supporting factors in increasing the learning activeness of students, each teacher must master the teaching methods and be able to manage the class well so as to create a conducive and active atmosphere in learning.

As happened in the field, besides that, there were also many teachers who did not master the room and the character of their own students. This can be proven from the observation that in the room when the teaching and learning process in the classroom has started, there are still many students who are noisy, disturbing friends and because of the teacher's inability to manage the class, a learning process is not conducive. The teacher cannot control the class because the students do not want to be calm, and besides that the teacher continues learning without paying attention to the students.

\section{b. Implementation of Hidden Curriculum by Teachers to Increase Learning Activeness of Students in SDN. 136539 Tanjungbalai}

Based on the results of observations, researchers conducted at SDN. 136539 Tanjungbalai on the implementation of the hidden curriculum carried out by Islamic Education teachers. Researchers have succeeded in finding several hidden curriculum implementations to increase students' learning activeness while the researcher observes, among others: (1) In the learning process, each student is required to say greetings and basmallah when asking and responding so as not to stutter in asking questions and giving responses. (2) In SDN schools. 136539, for class VI, it is mandatory to know about prayer intentions, prayer movements and the number of cycles of prayer and call to prayer. So, in the learning process before starting lessons, the teacher instructs some students to practice the prayers, with that students are very happy to move forward because they want to be praised as smart students pious. (3) At SDN. 136539, the school also ordered to memorize some already short. So, in the learning process, if there are students who want to ask questions. Apart from saying greetings and basamallah, you also have to read one of the short chapters. The goal, the teacher wants to find out whether the student has started memorizing one of the short surahs and training students to memorize the al-qur'an. (4) In the learning process, the student was instructed to make an accusation position like the letter (U) during the lesson on the story of the Exemplary of the Prophets 
because one of the students was ordered to read the Tauladan story of the Prophets and the student sat in the position of the letter (U) and listened carefully. (5) The teacher checks the hair, nails, clothes and all the appearance of the students in order to get used to living clean and tidy because in Islam, cleanliness is part of faith and so that in learning, students can be active in learning and enthusiastic in learning. (6) During the learning process, the teacher positions the students' seats according to their level of knowledge and characteristics. The teacher always provides motivation to students who ask and answer in the form of additional cues and values. In the learning process, if students seem noisy, bored and bored.

The teacher invites students to sing in Islamic nuances such as the song "Sepohon Kayu" or the teacher arouses students' enthusiasm by inviting chants. Like, the teacher says Islam, the student answers that Muslims are Beautiful. When the learning process takes place, one of the students is instructed to advance to explain what is understood about the material being studied, for example the material "Beautiful Names of Allah SWT". After one of the students is able to explain, the student has the right to choose one of the other friends to come forward to explain the same material and the student who has previously explained has the right to sit. In that process, the teacher motivates students to move forward and rewards them with values.

To increase learning activity, sometimes the teacher goes around to monitor students who are less disciplined, such as sleeping on a bench, telling unnecessary stories, hitting friends and so on. So, the teacher gives a light punishment, such as testing the memorization of the surah or asking for previous material. In the learning process, when reading the material "The Beautiful Names of Allah SWT", which consists of 4 parts of the material, namely: as-samad, al-muqtadis, al-muqaddim and al-baqi '. At that time, to increase learning activity, after the teacher explained the material, the teacher ordered 4 students to explain each one of the parts of the material. If, are brave and succeed in explaining the material, then the student will be given additional marks. At the beginning of learning, the teacher has repeated it in a unique way. For example, The teacher gives 4 gifts, in the form of a notebook and in the book a question that discusses the previous material is inserted. For example, in the first book, state the names of the last days. If you are successful in answering, you will get the book.

\section{c. Barriers Faced by Teachers in Applying in Applying Hidden Curriculum in SDN. 136539 Tanjungbalai}

Based on the researchers did this by conducting interviews with the mother of the PAI teacher Marheini Sitorus, S. Pd. There are several obstacles in implementing the hidden curriculum, namely: the mother's lack of understanding in the use of IT in the learning process, the lack of facilities and infrastructure in the learning process, the presence of students who are a little late in entering the learning process, mothers feel that is the only obstacle that is experienced.

\section{d. Supporting Factors, Obstacles, Solutions in Increasing Student Learning Activeness}

Based on the results of observations at SDN. 36539 Tanjungbalai, which have become a number of concerns for teachers, especially teachers of Islamic Education in implementing learning methods at SDN. 36539 Tanjungbalai, including the factors of students because of the different types of intelligence of students. In the process of implementing Islamic Education learning, the type of student intelligence is important that must be considered by every Islamic Education teacher in SDN. 136539 Tanjungbalai. The teacher does not pay attention to the types of intelligence that each student has.

Another inhibiting factor is from educators or field teachers who teach Islamic Education material at SDN. 36539 Tanjungbalai. The teacher's lack of understanding in the use of IT in the learning process, lack of facilities and infrastructure. The teacher delivered the material 
poorly so that the class had difficulties. The teacher does not know the needs of students who are needed to deliver lessons. Like the results of observations with the teacher while teaching, the strategies the teacher uses are not in accordance with the teaching material. As in the material on Let's Pay Zakat, where the teacher only uses the lecture method, even though in that material the teacher can use the Discussion and Assignment method, where the teacher can present a problem so that students think to find the problem and solve it.

As for solutions to the obstacles experienced, the teacher designs the class as beautiful as possible so that it looks beautiful and fun in learning, uses media that can increase the learning activity of students, makes rules with students in the learning process in terms of saying and returning greetings when starting learning or asking and answering, should not be late when entering class, tidy up the appearance from the feet to the hair so that it can increase the learning activity of students while studying.

\section{Conclusion}

Based on the results of research conducted on "the strategy of Islamic Education teachers in implementing a hidden curriculum to increase the learning activity of students in SDN. 136539 can be concluded, as follows: (a) PAI Teacher Strategies in Implementing Hidden Curriculum to Improve Student Learning Activeness in SDN. 136539 Tanjungbalai is by using methods in a teaching and learning process, including: (b) Active Learning Strategy is a teaching and learning strategy that aims to improve the quality of education to achieve student involvement in order to be effective and efficient in learning, various supporters are needed in the teaching and learning process. , namely from the point of view of students, teachers, learning situations, learning programs and learning facilities. (c) Contextual Learning Strategy is learning that links learning material with real-world contexts faced by students everyday in their family, community, and natural environment so that students are able to make connections between their knowledge and its application in everyday life, involving seven the main components of learning, namely: constructivism, asking, investigating, learning society, modeling, reflection and authentic assessment. (d) The Quiz Team is that each student in the team is responsible for preparing a short answer quiz and the other teams use their time to check notes. natural surroundings so that students are able to make connections between their knowledge and its application in everyday life, by involving the seven main components of learning, namely: constructivism, asking, investigating, learning societies, modeling, reflection and authentic assessment.

a. The implementation of the hidden curriculum carried out by PAI teachers, among others: In the learning process, each student is required to say greetings and basmallah when asking questions and responses so as not to stutter in asking and giving responses. At the SDN school. 136539, for class VI, it is mandatory to know about prayer intentions, prayer movements and the number of cycles of prayer and call to prayer. So, in the learning process before starting lessons, the teacher instructs some students to practice prayers, with that students are very happy to come forward because they want to be praised as smart, pious and pious students. At SDN. 136539, the school also ordered to memorize some already short. So, in the learning process, if there are students who want to ask questions. Apart from saying greetings and basamallah, also have to read one of the short chapters. The goal, the teacher wants to know whether the student has started memorizing one of the short surahs and training students to memorize the Koran.

b. At the beginning of learning, the teacher has repeated it in a unique way. For example, the teacher gave 4 gifts, in the form of a notebook and in the book a question that discussed the previous material was inserted. For example, in the first book, state the names of the last 
days. If you are successful in answering, you will get the book. With that, students are excited to learn and continue to repeat lessons at home. Sometimes, in asking or responding, the teacher only appoints disciplined students. For example, not telling stories with friends while studying and neatly dressed. At the beginning of the lesson, the teacher instructs students to pay attention to their surroundings if there is trash to throw into the trash. And sometimes the teacher explains to students to create a clean and healthy environment so that learning feels calm and active in the learning process. Obstacle factors in implementing the hidden curriculum, namely: the mother's lack of understanding in the use of IT in the learning process, the lack of facilities and infrastructure in the learning process, the presence of students a little late in the learning process. Supporting factors in increasing the learning activeness of students at SDN. 136539 Tanjungbalai, namely internal factors, factors that exist within these students, and external factors, namely factors that exist from outside the student, such as the environment. On the other hand, students have different conditions which basically like Islamic Education subjects so that they are eager to participate in the learning.

\section{References}

Abdullah Idi. (2007). Pengembangan Kurikulum Teori dan Praktik, Yogyakarta: Ar-Ruzz Media.

Abu Ahmadi dan Joko Tri Prasetya. (1997). Strategi Belajar Mengajar, Bandung: Pustaka Setia.

Akrim. (2020). Application of Learning Model Strategies to improve Islamic Learning Outcomes. Budapest International Research and Critics Institute-Journal (BIRCIJournal). P. 1157-1166.

Andi Prastowo. (2012). Metode Penelitian Kualitatif: Dalam Perspektif Rancangan Penelitian, Yogyakarta: Ar-Ruzz Media.

Aunurrahman. (2012). Belajar dan Pembelajaran, Bandung: Alfabeta.

Azizah Hanum OK. (2017). Filsafat Pendidikan Islam, Medan: Rayyan Press.

Depdiknas. (2000). Kurikulum Berbasis Kompetensi Mata Pelajaran Agama Islam, Jakarta: Pusat Kurikulum-Balitbang Depdiknas.

Dimyati dan Mudjiono. (2009). Dikutip dalam Skripsi Ana Karisma, Belajar dan Pembelajaran, Jakarta: Rineka Cipta.

Farida Jaya. (2018). Perencanaan Pembelajaran PAI, Medan: Fakultas Ilmu Tarbiyah dan Keguruan UIN Sumatera Utara.

Hadari Nawawi. (1998). Organisasi Sekolah dan Pengelolaan kelas Sebagai Lembaga Pendidikan, Jakarta: Tema Baru.

John M. Echols dan Hassan Shadily. (2005). Kamus Inggris-Indonesia, Jakarta: Gramedia.

Junaidi Arsyad. (2017). Metode Pendidikan Rasullullah SAW, Medan: Perdana Publishing.

Lexy J. Moelong. (2007). Metodologi Penelitian Kualitatif, Bandung: Remaja Rosdakarya.

Lias Hasibuan. (2010). Kurikulum dan Pemikiran Pendidikan, Jakarta: Gaung Persada,

M. Yatimin Abdullah. (2007). Studi Akhlak dalam Perspektif Alquran, Jakarta: Amzah.

Martimis Yamin. (2007). Kiat Membelajarkan Siswa, Jakarta: Gaung Persada Press.

Muh. Habib Ainun. (2014). Implementasi Hidden Curriculum di Sekolah Model Asrama, Jurnal Paradigma, Volume 2, Nomor 2.

Muhammad Fadhil al-Jamil. (1986). Filsafat Pendidikan dalam Alquran, Surabaya: Bina Ilmu. Murray Print. (2008). Sebagaimana dikutip dalam Wina Sanjaya, Kurikulum dan Pembelajaran: Teori dan Praktik Pengembangan Kurikulum Tingkat Satuan Pendidikan (KTSP), Jakarta: Kencana. 
Nana Syaodih Sukmadinata. (2008). Metode Penelitian Pendidikan, Bandung: Remaja Rosdakarya.

Ngainun Naim. (2009). Menjadi Guru Inpsiratif, Yogyakarta: Pustaka Pelajar.

Oemar Hamalik. (2004). Perencanaan Pengajaran Berdasarkan Pendekatan Sistem, Jakarta: Bumi Aksara.

Rakhmat Hidayat. (2011). Pengantar Sosiologi Kurikulum, Jakarta: Rajawali Pers.

Sipayung, T. et al. (2020). An Analysis of Students Motivation in Online Learning Based on Realistic Mathematical Comic Videos. Budapest International Research and Critics Institute-Journal (BIRCI-Journal).P. 3861-3871

Sugiyono. (2015). Metode Penelitian Pendidikan: Pendekatan Kuantitatif, Kualitatif, dan R\&D, Bandung: Alfabeta.

Suharsimi Arikunto. (2010). Prosedur Penelitian Suatu Pendekatan Praktik, Jakarta: Rineka Cipta.

Suryoubroo B. (1983). Beberapa Aspek Dasar Kependidikan, Jakarta: Bina Aksara.

Suyanto dan Asep Jihad. (2013). Menjadi Guru Profesional, Jakarta: Esensi.

UU No.20 Tahun 2003 tentang Sistem Pendidikan Nasional.

Undang-Undang RI Nomor 14 Tahun 2005, 2011. Tentang Guru dan Dosen, Bandung: Fokus Media,

W.J.S. Poerwadarminta. (1991). Kamus Umum Bahasa Indonesia, Jakarta: Balai Pustaka.

Wahyudin Nur. (2016). Strategi Pembelajaran, Medan: Perdana Publishing.

Wina Sanjaya. (2008). Kurikulum dan Pembelajaran: Teori dan Praktik Pengembangan Kurikulum Tingkat Satuan Pendidikan (KTSP), Jakarta: Kencana. 